\title{
The use of block and integrated practicum structures within employer-sponsored pre-registration nursing programmes: A Critical Realist study
}

\author{
Phil Coleman* \\ Faculty of Wellbeing, Education and Language Studies, School of Health, Wellbeing and Social Care, The Open University, \\ United Kingdom
}

Received: August 28, 2021

DOI: $10.5430 / j n e p . v 12 n 3 p 47$
Accepted: October 30, 2021

Online Published: November 9, 2021

\begin{abstract}
This study, underpinned by Critical Realism, explores the use of block and integrated placement frameworks within employersponsored pre-registration nursing programmes at a United Kingdom university. Digitally recorded, commercially transcribed semi-structured interviews involving four stakeholder groups (employers, students, mentors, and practice tutors), were exposed to qualitative content analysis, and yielded four common themes; connectedness, role transition, carer work and difference. Most respondents perceived the block model as being more effective in promoting connectedness, facilitating role transition, and mitigating against perceived difference; although use of the integrated model was considered more desirable for services having to release these students from carer work. Results also highlight various factors which may influence the most appropriate choice of practicum model, including individual student characteristics, the service in which learners undertake their non-registrant care work, the nature of the placement and mentor autonomy within their clinical role. Congruent with the principles of Critical Realism, efforts to establish potential underlying causative mechanisms associated with practicum experiences are underway and currently involves scrutiny of these results against key features of the Theory of Human Relatedness. Furthermore, a regression analysis to identify the statistical relationship between the placement model completed by two national cohorts and retention rates/degree classifications is in progress. This combined work contributes to the extremely limited body of knowledge in an important area of curriculum design within nurse education.
\end{abstract}

Key Words: Placement, Practicum, Duration, Intensity, Nurse education

\section{INTRODUCTION}

Practice learning is internationally recognised as a fundamental component of pre-registration nurse education. ${ }^{[1-7]}$ The language used to describe assignment of a student to a real clinical environment for the purpose of professional learning varies across different nations and healthcare disciplines and such activity is commonly and interchangeably known as a 'practicum', 'practice experience', 'rotation', 'practice education' or 'placement'. ${ }^{\text {' }}$ Whilst Eskilsson et al. ${ }^{[9]}$ claim that 'extensive research has been carried out about learning in clinical practice', Coleman ${ }^{[10]}$ asserts that most studies focus on the supervisory practices of clinicians and educators, rather than considering how placement duration and intensity may affect practice learning. Moreover, no single practicum design has yet been demonstrated to best facilitate such learning. ${ }^{[11-13]}$

\footnotetext{
*Correspondence: Phil Coleman; Email: phil.coleman@open.ac.uk; Address: Faculty of Wellbeing, Education and Language Studies, School of Health, Wellbeing and Social Care, The Open University, United Kingdom. 
A range of terminology is used to identify specific practicum models, but this diversity of language masks a reality that placements are commonly based on just one of two frameworks, namely a block or integrated design. Student activity in the block model alternates between dedicated placement periods lasting weeks or months and separate episodes of academic study. In contrast, the integrated model assigns some programme time each week for a practicum, commonly over several consecutive days, and the remaining time during the week is set aside for academic study activities, normally including attendance at formal teaching sessions. ${ }^{[14]}$

Within nursing and, indeed, other health and social care disciplines there has been remarkably little research examining the effect of block and integrated practicum designs on learner experiences and the small body of work to date fails to highlight any consistently preferred model. Whilst some studies have identified a preference for block placements amongst students, practitioners, and academics, ${ }^{[15-20]}$ others suggest more effective learning is derived from integrated placement experiences ${ }^{[21-24]}$ or show no statistically significant difference between the two designs. ${ }^{[25-27]}$ Several investigations suggest both models have inherent strengths and limitations associated with, for example, the integration of theory and practice, work-life balance, and participation as a team member within a practicum; often affected by how much programme study a learner has so far completed or this individual's personal circumstances. ${ }^{[12,28-30]}$

In the United Kingdom (UK), it has long been argued that non-registrant carer (NRC) experience may offer effective preparation for the practice demands imposed upon both Registered Nurses (RNs) and nursing students ${ }^{[31,32]}$ and that 'there is a strong case for improving access to nursing courses for experienced carers'. ${ }^{\text {[33] }}$ The university in which this research study was undertaken solely offers employersponsored pre-registration nursing programmes (ESPRNPs) It requires all applicants to be NRCs, to meet the minimum entry requirements of the Nursing \& Midwifery Council (the UK regulatory body), and to have employer support. Such support is an entry condition due to staff backfill costs and because the employer must arrange placements and appropriate mentors (recently re-termed 'practice assessors' in the UK). The student's employer selects a block or integrated practicum framework and, irrespective of this choice, learners resume their NRC duties outside placements.

Critical Realism is a 'relevant philosophical framework on which to base investigations within socially embedded, complex, empowerment focused, practice-based fields such as nurse education ${ }^{[34]}$ and one growing in popularity within nursing and wider healthcare research. ${ }^{[35,36]}$ Moreover, the approach has emancipatory aspirations ${ }^{[37,38]}$ and seeks to make pragmatic recommendations. ${ }^{[39,40]}$ This study, founded on Critical Realist principles, explores the use of block and integrated placements within ESPRNPs at a university with a UK-wide reach from the perspective of four stakeholder groups.

\section{Methods}

Digitally recorded semi-structured interviews commonly lasting thirty minutes and involving concurrent member checking, ${ }^{[41]}$ were undertaken with representatives of four groups involved in block and integrated practicum models used on ESPRNPs leading to BSc (Hons) awards in either adult (physical) or mental health (MH) nursing and entitlement to join the Nursing \& Midwifery Council register. Congruent with Critical Realism, purposive sampling was utilised. Interviews, based on a schedule agreed by two disinterested academics and piloted without subsequent revision, were held at times and locations chosen by the participants. All interviews were held face-to-face except some of those undertaken with mentors which took place remotely via video conferencing or telephone due to restrictions associated with the COVID-19 pandemic. Only the interviewer and respondent were present during recordings. No field notes were taken during the interviews although some, primarily related to clinical context, were made immediately afterwards. The semi-structured design meant that some supplementary questions and prompts were employed during the interviews to enhance data and facilitate understanding. No repeat interviews were held.

The four stakeholder groups were employers, students, practice tutors and mentors, all working within twelve healthcare organisations in northern England. The employers were managers within National Health Service (NHS) Trusts and who determined placement model selection. Mentors were experienced RNs employed by healthcare organisations in which ESPRNP learners were located and who assess student competence. Practice tutors were university staff monitoring ESPRNP learner progress and supporting students/mentors in practice settings. All learners in the study were mature students, a term used in the UK to describe individuals aged 21 years or older, ${ }^{[42]}$ who had completed more than one year of their programme and so undertaken several placements. The student practice learning experiences to which stakeholders referred took place in a wide range of clinical services providing physical and/or mental healthcare. These services were inpatient, outpatient or community-based and addressed acute, longer-term, or continuing care needs.

Invitations to participate were sent by email and nonrespondents were emailed again, two weeks later. Those who still failed to reply were not contacted further. Inter- 
views were undertaken by the researcher, a nursing academic at the university, who had no direct involvement with the student's education, nor held employment in any healthcare organisations included in the study. The researcher, however, had line management responsibilities for several practice tutor respondents. Written informed consent was sought and obtained from all participants and the study was approved by the university's research ethics committee. Data related to invitations to participate, acceptances, withdrawals and completed interviews for members of the four stakeholder groups are outlined in Table 1.

Table 1. Invitations to participate, acceptances and withdrawals

\begin{tabular}{lllll}
\hline $\begin{array}{l}\text { Stakeholder } \\
\text { subset }\end{array}$ & $\begin{array}{l}\text { Number } \\
\text { initially invited } \\
\text { to participate }\end{array}$ & $\begin{array}{l}\text { Number accepting } \\
\text { invitation to interview }\end{array}$ & $\begin{array}{l}\text { Number accepting invitation to interview } \\
\text { but subsequently withdrawing/not } \\
\text { responding to further communications }\end{array}$ & $\begin{array}{l}\text { Number } \\
\text { ultimately } \\
\text { interviewed }\end{array}$ \\
\hline Students & 55 & 13 & 0 & 12 \\
Mentors & 72 & 11 & 2 & 8 \\
Employers & 10 & 9 & 0 & 9 \\
Practice Tutors & 10 & 8 & 0 & 8 \\
\hline
\end{tabular}

Interviews continued until data saturation was achieved within each stakeholder group, hence two stakeholders (one student and one mentor) who accepted an invitation without subsequently withdrawing were still not ultimately interviewed. Audio recordings were commercially transcribed before analysis, which focused on manifest rather than latent content ${ }^{[43]}$ and was undertaken in accordance with the threestage model of qualitative content analysis described by Elo and Kyngas. ${ }^{[44]}$ Open coding and category creation was undertaken by the researcher, but the formulation of themes and general category descriptions were additionally scrutinised by a disinterested academic and modified in accordance with

Table 2. Sample characteristics and quasi-statistical data

\begin{tabular}{|c|c|c|c|c|c|}
\hline $\begin{array}{l}\text { Respondent subset } \\
\text { (Gender and Adult or MH } \\
\text { nursing) }\end{array}$ & $\begin{array}{l}\text { Respondent } \\
\text { experience of } \\
\text { block } \\
\text { placement } \\
\text { model } \\
\end{array}$ & $\begin{array}{l}\text { Respondent } \\
\text { experience of } \\
\text { integrated } \\
\text { placement model }\end{array}$ & $\begin{array}{l}\text { No } \\
\text { respondent } \\
\text { placement } \\
\text { model } \\
\text { preferred } \\
\end{array}$ & $\begin{array}{l}\text { Respondent } \\
\text { preference for } \\
\text { block } \\
\text { placement } \\
\text { model } \\
\end{array}$ & $\begin{array}{l}\text { Respondent } \\
\text { preference for } \\
\text { integrated } \\
\text { placement } \\
\text { model }\end{array}$ \\
\hline Students: 12 & 6 & 6 & 3 & 7 & 2 \\
\hline Female: 9 & Female: 6 & Female: 2 & Female: 2 & Female: 5 & Female: 1 \\
\hline Male: 3 & Male: 0 & Male: 2 & Male: 1 & Male: 2 & Male: 1 \\
\hline Adult: 8 & Adult: 4 & Adult: 4 & Adult: 4 & Adult: 4 & Adult: 1 \\
\hline MH: 4 & MH: 2 & MH: 2 & MH: 0 & MH: 3 & MH: 1 \\
\hline Mentors: 8 & 8 & 4 & $\mathbf{0}$ & 6 & 2 \\
\hline Female: 7 & Female: 7 & Female: 4 & Female: 3 & Female: 5 & Female: 2 \\
\hline Male: 1 & Male: 1 & Male: 0 & Male: 1 & Male: 1 & Male: 0 \\
\hline Adult: 5 & Adult: 5 & Adult: 3 & Adult: 4 & Adult: 5 & Adult: 2 \\
\hline MH: 3 & MH: 3 & MH: 1 & MH: 0 & MH: 1 & MH: 0 \\
\hline Employers: 9 & 9 & 3 & 1 & 6 & 2 \\
\hline Female: 9 & Female: 9 & Female: 3 & Female: 1 & Female: 6 & Female: 2 \\
\hline Adult: 7 & Adult: 7 & Adult: 1 & Adult: 0 & Adult: 6 & Adult: 1 \\
\hline MH: 2 & MH: 2 & MH: 2 & MH: 1 & MH: 0 & MH: 1 \\
\hline Practice Tutors: 8 & 8 & 6 & 3 & 3 & 2 \\
\hline Female: 8 & Female: 8 & Female: 6 & Female: 3 & Female: 3 & Female: 2 \\
\hline Adult: 5 & Adult: 5 & Adult: 3 & Adult: 2 & Adult: 2 & Adult: 1 \\
\hline MH: 3 & MH: 3 & MH: 3 & MH: 1 & MH: 1 & MH: 1 \\
\hline Total of respondent subsets: 37 & 31 & 19 & 7 & 22 & 8 \\
\hline
\end{tabular}

their feedback. No software was employed either to manage or analyse data. Participants were provided with the preliminary report related to the stakeholder group of which they were a member and invited to comment, although none proposed any revisions.

\section{Results}

\subsection{Quasi-statistics}

Quasi-statistics, ${ }^{[45]}$ outlining descriptive numerical data regarding respondent gender, programme of study, placement experiences and preferences are provided in Table 2. 


\subsection{Qualitative content analysis}

Qualitative content analysis yielded four themes common to all stakeholder groups interviewed, namely 'connectedness', 'role transition', 'carer work' and 'difference'. Illustrations within each theme are, wherever possible, drawn from all groups to facilitate fair dealing ${ }^{[46]}$ and key contradictory evidence $^{[47]}$ is highlighted. Respondents are identified by their role; namely employer $[\mathrm{E}]$, mentor $[\mathrm{M}]$, practice tutor $[\mathrm{P}]$ or student $[\mathrm{S}]$ and an identification number. Terms to facilitate comprehension of respondent comments are provided in brackets.

\subsection{Theme: Connectedness}

This theme reflects the importance participants assigned to ESPRNP students feeling they contribute to service delivery in a practicum, building effective working relationships and having consistent and coherent practice learning. Of those respondents across all sub-groups who expressed a practicum framework preference, most suggested the block model offered a learning experience better suited to fulfilling these goals. Specifically, a block placement was regarded as more effective in enabling students to become part of the team within a practicum:

E7: [a block practicum] 'aids integration to the team and therefore reduces anxieties, thus allowing the student to focus on their learning requirements'

P7: 'if they're full-time [block] on placement they kind of become more part of the team I think, than if they're in and out one or two days' [integrated practicum]

S2: 'On a block placement I don't know, I feel like you get to know people a lot more'

Respondents commonly suggested that a block practicum offered better opportunities for learners to meaningfully participate in group interactions that occurred during the placement and in which service team members presented their views and expressed their collective identity, for example, during staff development, case reviews or adverse event debriefing sessions.

Similarly, the opportunity for uninterrupted practice learning within a block practicum was highly valued:

E8: 'I think what they [ESPRNP students] feel is that it [block placement] does enable them to get immersed in the team that they're working in'

P1: 'The total immersion [of a block placement] works quite well because actually it's such unfa- miliar territory, it's very good [for the student] to get stuck in there'

S7: 'it's intense learning for those block placements. You're not pulled away at all, you're focused totally on the learning of the things they do on that ward or that placement'

Overall, responses suggested that the nature of the healthcare service in which the practicum took place may affect the extent to which a student had a consistent and meaningful practice learning experience. For example, services in which nursing intervention for a patient is unlikely to extend beyond several hours (such as care in an Emergency Room/Accident \& Emergency department, an out-patients clinic, or input from a mental health crisis team) or that was likely to last more than several weeks (such as community nursing care for chronic/enduring conditions, an orthopaedic trauma ward, or a forensic in-patient mental health unit) were generally perceived as more appropriate for an integrated placement. This was largely because respondents believed such a practicum would not adversely affect and may even increase the probability of the student observing, understanding, and engaging in, the entire patient journey within the service:

P2: [In block placements] 'if you're there you won't see the patient, perhaps, from admission to discharge, whereas if you're there over nine weeks [integrated practicum] you may see them'

In contrast, a block placement was seen as more desirable within services in which nursing intervention for a patient commonly lasted between several days and one or two weeks (such as a medical, surgical, or acute mental health in-patient ward) because the model was, once again, deemed to optimise the likelihood of the student being exposed to the provision of nursing care for the entirety of a patient's engagement with the service:
M5: [An ESPRNP student on a block practicum is] 'able to develop a relationship with that per- son. She could care plan, she could risk as- sess, and she actually could see it through to discharge'

The extent to which a mentor has control over their personal workload and so could adjust it to accommodate individual student learning needs and best develop an effective working relationship with the nursing students whom they supported also appeared to influence practicum model preference. Those mentors who had a high degree of autonomy and scope for controlling their working week perceived integrated placements more positively, highlighting the potential 
this structure offered for them to plan events from which a learner might derive greatest benefit on placement days and ring-fence time for their administrative work (which was deemed to be of limited learning value), on other working days:

M4: 'for me it's quite good not having a student constantly. So you have that, you can give them the time. Because you know they're with you on a set day or two days, you can alter your workload... Yes, I think oh that will be really good experience for her [ESPRNP student], we'll do that on that day when she's here'

Mentors with little or no control over planning their working week, however, generally expressed a preference for block placements; commonly suggesting that this design was more likely both to optimise their interaction with the student and the associated learning opportunities such contact afforded:

M5: 'I've got two discharges today for instance and they have to happen, they simply have to happen. I can't wait until that student comes back on Monday to allow that student to experience the discharge process'

What capacity exists within a placement for mentor-student discussion, facilitating student reflection on practice and consolidation of their learning was another factor which appeared to affect the perceived quality of practice learning derived from the clinical experience. Whilst integrated placements were regarded as offering more scope to reflect upon and consolidate learning, time within a block placement for such activity was described as more problematic:

S1: [with an integrated practicum] 'you get time to go through it in [a] much more relaxed way, rather than crowding it at one particular point'

M8: it was only like a short full time [block] placement, so we did struggle... We did spend a few days together, but a lot of the time it would be putting her [ESPRNP student] with other team members and getting them to feed back'

In summary, respondents perceived connectedness as critical to effective practice learning. Most believed it was best promoted by a block practicum, although several participants offered notable and impassioned arguments to support use of an integrated placement design.

Published by Sciedu Press

\subsection{Theme: Role transition}

This theme reflects challenges associated with concurrently being an NRC and ESPRNP student. The difficulty in transition and potential for role conflict was widely recognised by almost all respondents who commonly highlighted variation in the skills and conduct expected within these two roles. Once again, most interviewees believed a block practicum was more likely to reduce the risk of problems associated with such role transition:

E9: 'it's much easier in a block [placement] to remember who you are and what you do and what your job role allows you to do. It gives them six weeks of being a student nurse. It's not 'what hat do I have on today?"

P4: 'Most students who were on block placements found it easier, because what they then say to me was that during the time when they're on placement they don't actually have to think about their role as a healthcare assistant' [NRC]

S3: 'when I come out of my AP [NRC] uniform and put my student uniform on for those four or five-week blocks that I'm doing, I am a student and I've accepted that. So personally I've found that easier with the transition'

Support for the block model to mediate the challenges of role transition was not, however, unanimous. Some respondents highlighted problems with this framework and advantages to an integrated practicum:

P3: 'if you've had a student out in practice on a block placement, once that block placement comes to an end does it [they] then have difficulty in reverting back to the HCA [NRC] role'

M2: 'the students felt a sense of security maybe that they still kept their healthcare [NRC] role, but had one shift a week where they could concentrate on being the student nurse'

M4: 'they then have the opportunity [in an integrated practicum] to come back and say oh this happened at work and I was a bit uncomfortable with this, what would you have done? Do you think we could have done something different? Discuss it. They then take that back, the next week they'll come back, oh well actually I did say this. So they have, whereas normally in a block [placement] you don't have that opportunity' 
It was also evident that, whilst some students had contributed to the decision-making process associated with the type of placement model they were assigned, others had not been consulted and were even unaware that two practicum options were available. Moreover, learning that their employer decided upon a placement model without taking their views into account was received with surprise and some irritation:

S7: 'I don't know why they [employer] would [choose the block model for placements]; I do believe the other one [integrated placements] works better for personal, well personal and professional [reasons]'

S6: 'I'm annoyed that I wasn't given the option of the other one [block practicum]. Only because it's hard. Firstly, you never know what hat you're putting on in a morning. You've got to switch from one to the other'

For some, transitioning between NRC and ESPRNP student roles within the selected practicum model also had wider implications; for example, affecting the student's social and financial circumstances. Commonly, advocates of an integrated practicum highlighted these wider implications in the rationale for their placement model preference:

S7: 'I've got children to get to school and things like that. So having two days a week [integrated practicum] would be much better personally than having the full block placement and having to cover four weeks, six weeks, ten weeks of childcare'

S12: 'from a financial perspective if I was fulltime on [block] placement, I'd lose out on enhancements' [additional NRC unsocial hours payments]

Overall, the block practicum was therefore deemed best suited to minimising the challenges of role transition for ESPRNP students. Nevertheless, a notable group of respondents highlighted the benefits of integrated placements in facilitating reflection and consolidation of learning, avoiding the sudden insecurity of entirely losing a familiar NRC role and better accommodating the student's personal circumstances beyond their commitments as an employee and nursing student.

\subsection{Theme: Carer work}

This theme captures the implications of having an NRC who is also an ESPRNP student for the service where this individual is employed. The beneficial effects of transferable ESPRNP student learning to their employment base was widely acknowledged amongst all respondent groups. Nonetheless, various tensions associated with responding to service needs and accommodating placements for NRCs on the ESPRNPs were also acknowledged. Some respondents believed a block practicum made it easier for a service to release an employee to undertake student placements:

E6: 'It was felt like it would be easier to get cover within the AP's [NRC's] usual workplace for a block time'

S4: 'easier to cover my hours as a block than two days a week. If they've got a good run of getting someone to cover for quite a while'

Block practicum advocates also suggested this framework reduced the risk ESPRNP student placements were cancelled to satisfy service demands:

P7: [with the integrated model] 'there's always the likelihood you'll get dragged back into the day-to-day routine of 'you're a healthcare assistant [NRC] and we need you today, so you can't go on placement"

Most respondents, however, deemed the integrated practicum model preferable for the service where the student is employed in their NRC role:

M2: [During integrated placements] 'they're not out for a whole block from their healthcare assistant [NRC] role, so they don't lose touch with developments in the service [and] managers do have staff continuity'

S12: 'you're not gone from the ward. if it's only two days a week, you're still there constantly, you're not disappearing for eight weeks at a time'

The retention of an NRC within the workplace, albeit at a reduced level, made possible by the integrated practicum model was most highly valued in those instances where staff backfill was not provided or where this member of staff had specialised knowledge or skills that might be difficult to replace if they were to be entirely absent from the workplace for weeks at a time due to a block placement:

E1: 'Other teams have not got backfill, so they're kind of absorbing that cost themselves where they've not been able to replace that person'

M2: 'Well it [an integrated practicum] was beneficial for us because she was able to continue 
doing the job that she'd been doing prior to starting the training. She had quite an important role in that she managed the diabetic side of our intravitreal injections, and she knew all the patients, when they were due and everything'

Students also reported concerns about a risk of deskilling within their NRC role, how an integrated practicum might mitigate against this risk, and the damage block placements could have on relationships with staff in their employment base:

S12: 'If I was gone for whatever length of time, let's say ten weeks, I'd feel uncomfortable coming back [from a block placement] because I'd feel like 'right what have I missed, how much has changed?"

S11: 'obviously [within the integrated model] I'm still here in my capacity as a healthcare assistant [NRC] so I'm still keeping all of those skills up to date'

The impact of undertaking a block practicum on workplace colleagues was felt most acutely by those students whose NRC work involved their holding a caseload, since this necessitated re-assignment of work amongst other team members:

S7: 'they're already overloaded [workplace colleagues] and I'm handing my caseload back to them [going on a block placement], so I feel awful'

The normal duration of nursing intervention for a patient within the service, the potential effect of staff and workload changes on the quality of care provision, the specific nature of the NRC's role in their workplace as well as the reduced risk that scheduled practicum time was cancelled at the eleventh hour all appeared, therefore, to be key stakeholder considerations. Most respondents regarded use of integrated placements as most advantageous for the service where an NRC who is also an ESPRNP student is employed.

\subsection{Theme: Difference}

This theme captures participants' reflections on the way ESPRNP students are perceived as different to conventional open entry nursing students and efforts to minimise such difference. Most respondents identified differences between these two groups of learners; largely related to the enhanced level of knowledge, skill, and experience that ESPRNP students possessed by virtue of their NRC work prior to programme entry. At the time, all open entry pre-registration

Published by Sciedu Press undergraduates on nursing degree programmes in the region were allocated block placements and employer respondents who selected a block practicum model for their ESPRNP students acknowledged that mitigating difference and standardising operational arrangements were key considerations underpinning this choice:

E4: [the block model] 'keeps [ESPRNP] students in line with other students and other learners that's on the ward as well. I think particularly for students who are only going in for two days a week [integrated practicum], they would probably be a bit lower down the priority list from a mentor's point of view'

E9: 'although probably that's not the right reason [to use the block model], it's familiarity. Mentors are very familiar with students coming every single day for a set period of time and actually that familiarity will continue to make them comfortable in their role as a mentor'

Indeed, respondents noted that inconsistency in the type of placement for nursing students from different universities might adversely affect the learning environment and interpersonal relations within the practice setting; hence the desire to align the practicum arrangements of ESPRNP undergraduates with those in place for the more numerous learners from other academic institutions on open entry programmes:

E1: 'So a [ESPRNP] student might go into an area where the mentor is not familiar. So it might be 'what are we going to do with you, what's different about your programme?"

P1: 'Initially they [ESPRNP students] sort of felt a little bit as though they're outside the norm and possibly even, I don't mean second class but sort of - I'm not a regular student therefore am I as valued as a regular student?'

For employer respondents the desire to minimise difference, however, was in tension with recognition that an integrated placement model could be used to optimise mentor and placement capacity:

E1: 'it can be easier to place a student on a clinical area if they're in the split [integrated] model, because it's not such a burden on placements where they have continual students from other areas, other HEIs' [universities]

E3: 'people who do the part-time [integrated] placement, so the two days a week, they don't necessarily get counted in the capacity numbers because it's not a fulltime placement' 
Striving to minimise the extent to which staff in clinical services perceived differences between ESPRNP students and learners on other nursing programmes was a common motivating factor which underpinned the selection of a block practicum. Where resource and operational issues might necessitate such learners having an integrated placement, several employers described how they had considered whether a service had previously accommodated students on both practicum models and whether a potential mentor in the location had experience of supporting students on an integrated placement before any student assignment was made. Moreover, where a service and/or mentor was unfamiliar with the ESPRNP and/or use of an integrated practicum, they reported significant efforts to convey this alternative provision in a positive way when briefing nursing staff in the location.

\section{Discussion}

\subsection{Locating the findings}

Although lacking unanimity, most respondents in these stakeholder groups who expressed a practicum framework preference supported use of the block model; perceiving it better able to promote connectedness, reduce the challenges ESPRNP students may face in respect of role transition and mitigate against perceived programme and student difference. The desire for block placements amongst these more experienced students is consistent with results from earlier work involving third- and fourth year undergraduate nursing students in Canada ${ }^{[12,30]}$ and Ghana, ${ }^{[20]}$ as well as newly qualified Occupational Therapists in Malta who were asked to reflect on their training experiences, ${ }^{[15]}$ but the possibility student preference for this placement structure may be different during the earlier stages of the programmes should not be overlooked. Furthermore, one cannot disregard the attractiveness of the well-known as an influencing factor. That is to say, the stronger preference for the block model may also be driven by greater familiarity with this practicum model (given that most nursing student placements on programmes offered by universities serving the area in which this study was undertaken were based on this design). Respondents, however, suggested the integrated model offered greater organisational and operational benefits to the location where the ESPRNP student normally undertakes their NRC work.

Table 3. Variables and key considerations in determining the potential suitability of a practicum model for an ESPRNP student

\begin{tabular}{|l|l|}
\hline Variable & Key considerations: \\
\hline Student characteristics & $\begin{array}{c}\text { - Whether the student has significant non-work commitments (such as parental or informal } \\
\text { carer responsibilities) }\end{array}$ \\
& $\begin{array}{l}\text { - Whether the student holds a caseload in their substantive employment role } \\
\text { - What, if any, preference a student indicates in respect of their model of practice learning }\end{array}$ \\
\hline $\begin{array}{l}\text { The service in which the ESPRNP } \\
\text { student is normally employed in } \\
\text { their NRC role }\end{array}$ & $\begin{array}{l}\text { - The duration of any single period of nursing intervention for a patient within the service } \\
\text { - The effect of staffing changes on the quality of care }\end{array}$ \\
\hline & $\begin{array}{l}\text { - What, if any provision has been made for staff backfill during ESPRNP student absence } \\
\text { - The duration of any single period of nursing intervention for a patient within the service, } \\
\text { from shorter-term (such as an Emergency Room/Accident \& Emergency department, } \\
\text { out-patients clinic or a mental health crisis team) to longer-term (such as community } \\
\text { nursing care for chronic/enduring conditions, an orthopaedic trauma ward or a forensic } \\
\text { in-patient MH unit) and its effect upon student understanding of, and engagement in, the } \\
\text { patient journey } \\
\text { - Whether the placement concurrently accommodates nursing students from other } \\
\text { universities and whether any inconsistency in the placement models to which these } \\
\text { different students are exposed might adversely affect the learning } \\
\text { environment/interpersonal relations } \\
\text { - What provision is available in the placement to facilitate student reflection on practice } \\
\text { and the consolidation of learning } \\
\text { - How the team within the placement normally communicate, express, and consolidate } \\
\text { their collective identity } \\
\text { - Whether a placement has previously accommodated students on both practicum models }\end{array}$ \\
$\begin{array}{l}\text { - The extent to which the mentor has control over their personal workload and can } \\
\text { therefore adjust it to accommodate individual student learning needs }\end{array}$ \\
- Whether the mentor has previously supported students on both practicum models \\
\hline The mentor
\end{tabular}




\subsection{Influencing factors and related recommendations}

For Critical Realist researchers, recommending changes and promoting emancipatory outcomes are regarded as central to effective academic enquiry. In this study, variation in stakeholder views on the desirability of both practicum models appears to have been affected by four key variables evidenced within the themes; namely the student's personal circumstances, the service where the ESPRNP student is normally employed as an NRC, the nature of the placement and the clinical role undertaken by the mentor. Issues in respect of these variables are summarised in Table 3 and, based upon the results of this study combined with the findings of earlier research involving more experienced pre-registration healthcare students, should arguably be carefully considered when seeking to determine the most suitable practice learning model for individual ESPRNP students. Doing so may not only improve the practicum experience for all key stakeholders but also help overcome oppressive or unjust structures, systems or behaviours related to placement design and thereby promote emancipatory changes to student learning.

\subsection{Limitations}

This research involved stakeholders from a relatively small geographical area, all of whom were involved in ESPRNPs delivered by only one university. The researcher was not a disinterested third party, although his prior interaction with virtually all stakeholder participants for other purposes was either limited or absent.

\section{CONClusion}

The study identifies an overall preference across the four respondent groups for use of the block practicum model and indicates the importance employers assign to minimising any perceived difference of these ESPRNPs compared to those open-entry programmes delivered by other universities also operating within their healthcare organisation. Most participants regarded immersion in a practice learning environment, acquiring a sense of belonging within the team and having a clear and sustained break from the NRC role as critical to the effective development of a distinct identity as a nursing student and that a block practicum best fulfilled all these goals. Whilst geographically and institutionally specific, the findings still contribute to the small body of knowledge currently available regarding the influence duration and intensity of a practicum may have on practice learning and appears to offer the only study to date which focuses on the block and integrated placement models in the context of ESPRNPs.

The next phase of this research, currently underway, involves a quantitative analysis to identify any relationship between the placement model experienced by ESPRNP students and programme retention/degree classification for two UK-wide cohorts, involving over 450 students. It will be interesting to see whether the block practicum preferred by most stakeholders is associated with reduced student attrition and higher academic achievement. Furthermore, aligned with a Critical Realist approach, additional work is being completed to provide a 'theoretical description of mechanisms and structures, in order to hypothesize how the observed events can be explained' ${ }^{[48]}$ by analysis of the qualitative results against key features within the Theory of Human Relatedness. ${ }^{[9]}$

It is anticipated that these investigative activities will stimulate further academic discussion on the topic, encourage additional research within this field and facilitate more considered and targeted utilization of practicum models for clinical learning. Further work to consider, apply and evaluate the variables outlined in Table 3 when assigning ESPRNP students to a block or integrated practicum model may be particularly valuable. Similarly, greater consideration of the placement type on providing emancipatory student learning experiences warrants more detailed scrutiny. Nevertheless, given the range of factors which may affect the suitability of a placement model, it seems highly unlikely that either design will be more desirable and emancipatory under all conditions. As a study participant commented, [P3] 'you wouldn't use just one intervention or one treatment for a patient, so you wouldn't use one education system to meet all student needs'; hence academic investigations related to the effectiveness of block and integrated placements and the efforts of educators to facilitate an individualised approach to practicum model selection must be maintained and developed.

\section{ACKNOWLEDGEMENTS}

I would like to thank university colleagues managing nursing provision in northern England for their thought-provoking discussion in respect of the concepts examined in this paper and for the enthusiastic participation of the stakeholder respondents.

\section{CONFlicts OF InTEREST Disclosure}

The author declares that there is no conflict of interest.

\section{REFERENCES}

[1] Simmons C, Williams A. Chapter one. Introduction: a professional journey in Simmons, C., Williams, A., Sher, S. \& Levett-Jones, T. (eds) Work Ready. E-Portfolios to Support Professional Placements Sydney, Office for Learning and Teaching 2012. 145p.

[2] Sandy P. Factors Affecting Assessment of Student Nurses' Clini- 
cal Practice: A Phenomenographic Exploration of the Experiences and Understanding of Mentors of a Mental Health Service in England. International Journal of Education Science. 2014; 7(1): 57-66. https://doi.org/10.1080/09751122.2014.11890169

[3] Tastan S, Iyigun E, Ayhan H, et al. Experiences of Turkish undergraduate nursing students in the intensive care unit. Collegian. 2015; 22(10): 117-123. PMid:26285416 https://doi.org/10.1016/j . colegn.2013.12.003

[4] El Mokadem N, Ibraheem S. Nursing Students' Satisfaction with Their Clinical Learning Environments. American Journal of Nursing Research. 2017; 5(4): 104-108. https://doi.org/10.12691/a jnr-5-4-1

[5] Morley D, Wilson K, McDermott J. Changing the practice learning landscape. Nurse Education in Practice. 2017; 27: 169-171. PMid:28416143 https://doi.org/10.1016/j.nepr.2017.03 .010

[6] Ntho T, Pienaar A, Sehularo L. Peer-mentees' challenges in an undergraduate peer-group clinical mentoring programme in a nursing education institution. Health SA Gesondheid. 2020; 25(a1435): 1-8. https://doi.org/10.4102\%2Fhsag.v25i0.1435

[7] Woo M, Li W. Nursing students' views and satisfaction of their clinical learning environment in Singapore., Nursing Open. 2020; 7(6): 1909-1919. PMid:33072376 https://doi.org/10.1002/ nop2.581

[8] Asare H. Student Radiographers' Perceptions of Clinical Placement: a Survey in Ghana. Journal of Radiology \& Radiation Therapy. 2017; 5(3): 1-5. https://www.jscimedcentral .com/Radiolo gy/radiology-5-1075.pdf

[9] Eskilsson C, Hörberg U, Ekebergh M, et al. Student nurses' experiences of how caring and learning is intertwined - A phenomenological study. Journal of Nursing Education and Practice. 2014; 4(2): 82-93. https://doi.org/10.5430/jnep.v4n2p82

[10] Coleman P. "Yes, the type of student supervision matters, but what about the placement structure?" - A critical realist review of block and integrated practice learning models within pre-registration nursing programmes. Journal of Nursing Education and Practice. 2021; 11(1): 39-50. https://doi.org/10.5430/jnep.v11n1p39

[11] Bourgeois S, Drayton N, Brown A. An innovative model of supportive clinical teaching and learning for undergraduate nursing students: The cluster model. Nurse Education in Practice. 2011; 11: 114-118 PMid:21185231 https://doi.org/10.1016/j.nepr.2010.11 .005

[12] Rohatinsky N, Chachula K, Compton R, et al. Nursing Student Preference for Block Versus Nonblock Clinical Models. Journal of Nursing Education. 2017; 56(3): 152-157. PMid:28263353 https://doi.org/10.3928/01484834-20170222-06

[13] Bhagwat M, Hewetson R, Jones L, et al. Comparison of paired and single clinical placement models: a time-use analysis. International Journal of Language \& Communication Disorders. 2018 53(3): 468-479. PMid:29218762 https ://doi .org/10.1111/14 $60-6984.12360$

[14] Uys L, Gwele N. Curriculum Development in Nursing. Process and Innovations. Abingdon, Routledge; 2005. 252p.

[15] Bonello M. Perceptions of fieldwork education in Malta: Challenges and Opportunities. Occupational Therapy International. 2001; 8(1): 17-33. PMid:11823868 https://doi.org/10.1002/oti.129

[16] Rock L, Ring K. Evaluating the One-Year Block Placement in Field Instruction, Revista de Asistenta Sociala. 2010; 9(4): 175-184.

[17] Sheepway L, Lincoln M, Togher L. An international study of clinical education practices in speech-language pathology. International Journal of Speech-Language Pathology. 2011; 13(2): 174-185. PMid:20626316
[18] Peters K, Halcomb E, McInnes S. Clinical placements in general practice: Relationships between practice nurses and tertiary institutions. Nurse Education in Practice. 2013; 13: 186-191. PMid:23069694 https://doi.org/10.1016/j.nepr.2012.09.007

[19] Coghill E. An evaluation of how trainee nursing associates (TNAs) balance being a 'worker' and a 'learner' in clinical practice: an early experience study. Part 1/2. British Journal of Healthcare Assistants. 2018; 12(6): 280-286. https://doi.org/10.12968/bjha. 2018 .12 .6 .280

[20] Amertil N, Ayitey E, Kpongboe D. Assessing the effects of clinical placement models on undergraduate nursing students in a private university in Ghana. International Journal of Health Science Research. 2020; 10(11): 188-197. https://doi.org/10.21203/rs.2.21 $536 / \mathrm{v} 2$

[21] Ranse K, Grealish L. Nursing students' perceptions of learning in the clinical setting of the Dedicated Education Unit. Journal of Advanced Nursing. 2007; 58(2): 171-179. PMid:17445020 https: //doi.org/10.1111/j.1365-2648.2007.04220.x

[22] Kevin J, Callaghan A, Driver C, et al. A possible alternative model of clinical experience for student nurses. Journal for Nurses in Staff Development. 2010; 26(5): e5-e9. PMid:20885138 https: //doi.org/10.1097/NND. 0b013e3181b1ba07

[23] Vanson T, Bidey T. Introduction of Nursing Associates. Year 2 Evaluation Report. London, Health Education England. 2019 64p. https://allcatsrgrey.org.uk/wp/download/nursin g/TNA-Year-2-Evaluation-Report_0.pdf

[24] Boardman G, Lawrence K, Polacsek M. Undergraduate student nurses' perspectives of an integrated clinical learning model in the mental health environment. International Journal of Mental Health Nursing. 2019; 28: 96-104. PMid:29897671 https ://doi.org/10 $.1111 /$ inm. 12496

[25] Theriot M, Johnson T, Mulvaney M, et al. Does Slow and Steady Win the Race? The Impact of Block versus Concurrent Field on BSW Students' Professional Development and Emotional WellBeing. Journal of Baccalaureate Social Work. 2006; 12(1): 203-217. https://doi.org/10.18084/1084-7219.12.1.203

[26] Sheepway L, Lincoln M, McAllister S. Impact of placement type on the development of clinical competency in speech-language pathology students. International Journal of Language \& Communication Disorders. 2014; 49(2): 189-203. PMid:24182204 https : //doi.org/10.1111/1460-6984.12059

[27] Perry R, Press M, Rohatinsky N, et al. Pilot study: Nursing students' perceptions of the environment in two different clinical models. International Journal of Nursing Sciences. 2016; 3: 285-290. https://doi.org/10.1016/j.ijnss.2016.07.001

[28] Curl A, Cary S. A Program Evaluation of Block and Concurrent Practicum Formats. Field Scholar. 2014; 4(2): 1-10. https: //fieldeducator.simmons.edu/article/a-program-eva luation-of-block-and-concurrent-practicum-formats /

[29] Birks M, Burkot C, Bagley T, et al. The impact of clinical placement model on learning in nursing: A descriptive exploratory study. Australian Journal of Advanced Nursing. 2017; 34(3): 16-23. https: //www.ajan.com.au/archive/Vol34/Issue3/2Birks.pdf

[30] Rohatinsky N, Chachula K, Sedgwick M, et al. Comparison of Nursing Student and Instructor Preferences for Block and Nonblock Clinical Models. Nurse Educator. 2018; 43(4): E1-E6. PMid:28991032 https://doi.org/10.1097/NNE.0000000000000458

[31] Gould D, Carr C, Kelly D, et al. Seconding health care assistants to a pre-registration nursing course: Evaluation of a novel scheme. NT Research. 2004; 9(1): 50-63. https://doi.org/10.1177/1361 40960400900110 
[32] Urwin S, Stanley R, Jones M, et al. Understanding student nurse attrition: Learning from the literature. Nurse Education Today. 2010; 30: 202-207. PMid:19910083 https : //doi.org/10.1016/j.ne dt . 2009.07.014

[33] Cavendish C. The Cavendish Review. An Independent Review into Healthcare Assistants and Support Workers in the NHS and social care settings. London: Department of Health and Social Care; 2013, 93p.

[34] Coleman P. A Critical Realist review of practice learning experiences within pre-registration nursing programme. EAS Journal of Nursing and Midwifery. 2020; 2(6): 202-212. https://doi.org/10.363 49/EASJNM. 2020.v02i03.008

[35] Terry K. The competency landscape: a critical realist exploration of the ways nurses understand and utilise competency standards [Doctoral Thesis], [Hobart]: University of Tasmania; 2013. 285p. https : //eprints.utas.edu.au/17166/

[36] Bakhshi M, Ranjbar H, Heydari A. Critical realism: an important philosophical perspective for nursing researches. Journal of Torbat Heydariyeh University of Medical Sciences. 2015; 3(3): 56-62. http://jms.thums.ac.ir/article-1-324-en.html

[37] Wilson V, McCormack B. Critical realism as emancipatory action: the case for realistic evaluation in practice development. Nursing Philosophy. 2006; 7(1): 45-57. PMid:16412202 https://doi.or g/10.1111/j.1466-769x.2006.00248.x

[38] Dammak A. Research Paradigms: Methodologies and Compatible Methods. Veritas. The Academic Journal of St Clements Education Group. 2015; 6(2): 1-5. http: //www.stclements . edu/Veritas /VERITAS $\% 200$ ctober $\% 202015$.pdf

[39] O'Mahoney J, Vincent S. Chapter 1. Critical Realism as an empirical project: a beginner's guide in: Edwards, P., O'Mahoney, J. \& Vincent, S. (eds). Studying organizations using critical realism. A practical guide. Oxford University Press. 2014; 376p. https: //doi.org/10.1093/acprof : oso/9780199665525.003.0001
[40] Corry M, Porter S, McKenna H. The redundancy of positivism as a paradigm for nursing research. Nursing Philosophy. 2018; 20(e12230): 1-10. PMid:30431226 https://doi.org/10.1111/ nup. 12230

[41] Beuving J, de Vries G. Doing Qualitative Research. The Craft of Naturalistic Inquiry. Amsterdam University Press; 2015, 220p.

[42] James N, Beck V. The perils of disregarding older learners in higher education. HE: Transforming lives through life-wide-learning? Conference 2016; 27-28; The Open University, Milton Keynes. Available from: https://www.open.ac.uk/about/wideningparticipation /events/biennial-wp-conference/wp-conference-2016

[43] Graneheim U, Lundman B. Qualitative content analysis in nursing research: concepts, procedures and measures to achieve trustworthiness. Nurse Education Today. 2004; 24: 105-112. PMid:14769454 https://doi.org/10.1016/j.nedt.2003.10.001

[44] Elo S, Kyngas H. The qualitative content analysis process. Journal of Advanced Nursing. 2008; 62(1): 107-115. PMid:18352969 https : //doi.org/10.1111/j.1365-2648.2007.04569.x

[45] Maxwell J. A Realist Approach for Qualitative Research. Los Angeles, Sage 2012; 240p.

[46] Mays N, Pope C. Assessing quality in qualitative research. British Medical Journal. 2000; 320: 50-52. PMid:10617534 https://doi . org/10.1136/bm j.320.7226.50

[47] Anderson C. Presenting and Evaluating Qualitative Research. American Journal of Pharmaceutical Education. 2010; 74(8): Article 141 PMid:21179252 https://doi.org/10.5688/aj7408141

[48] Bygstad B, Munkvold B. In Search of Mechanisms. Conducting a Critical Realist Data Analysis. Thirty Second International Conference on Information Systems; 2011 Dec 4-7; AIS, Shanghai.

[49] Hagerty B, Lynch-Sauer J, Patusky K, et al. An Emerging Theory of Human Relatedness. Journal of Nursing Scholarship. 1993; 25(4): 291-296. PMid:8288296 https ://doi .org/10.1111/j.1547-5 $069.1993 . t b 00262 . x$ 